\title{
Role of Rhizobium on Growth and Development of Groundnut:
}

\section{A Review}

\author{
Jnana Bharati Palai*11, G.C. Malik ${ }^{2}$, Sagar Maitra ${ }^{1}$ and Mahua Banerjee ${ }^{2}$ \\ ${ }^{1}$ Department of Agronomy, M.S. Swaminathan School of Agriculture, Centurion University of Technology and Management, \\ Paralakhemundi, Odisha, India \\ ${ }^{2}$ Department of Agronomy, Palli-Siksha Bhavana, Visva-Bharati, Sriniketan, West Bengal, India
}

*Corresponding author: jnana@cutm.ac.in (ORCID ID: 0000-0002-5565-2765)

Paper No. 882

Received: $17-01-2021$

Revised: 24-02-2021

Accepted: 14-03-2021

\begin{abstract}
To fulfill the demand of increased population it is very essential to enhance crop productivity with precise inputs. Non-judicious application of inorganic fertilizers and other agrochemicals is degrading soil health, creating environmental pollution and also contributing to climate change. Nowadays, people became more aware towards health risks and demand for quality foods with less chemical residues is increasing as there is a progression of demand for organic products. But it is very difficult to produce adequate quantity of organic foods for the raised population in the developing countries as per standard organic practices. That's why judicious use of inorganic fertilizers, organic manures and biofertilizers is required to supply nutrients to crops. Plant growth promoting rhizobacteria (PGPR), such as Rhizobium inoculation in groundnut (a major oilseed crop) can boost crop growth and enhance yield in a sustainable manner. Further, Rhizobium has multifaceted advantages in crop nutrient uptake and soil quality improvement. The article described the role of PGPR as well as Rhizobium in growth and productivity of groundnut towards production sustainability.

\section{Highlights}

0 PGPR improves plant growth by increasing nutrient uptake, secreting growth promoting hormones, showing antagonistic effect to pest and diseases and reducing adverse effect of heavy metals and other pollutants.

( Rhizobium inoculation in groundnut results in higher growth and yield attributes which determines higher pod, kernel and oil yield.

- Rhizobium inoculation also helps in raising other beneficial micro-organisms such as Arthrobacter simplex, Bacillus laevolacticus, B. amyloliquefaciens, Pseudomonas denitrificans, and P. rathonis and residual soil fertility.
\end{abstract}

Keywords: Groundnut, growth, productivity, PGPR, Rhizobium, sustainability

In last decade, human population in the world has increased substantially and it is expected to increase by 2 billion people in next 30 years, 7.8 billion in 2020 to 9.9 billion in 2050 (IISD 2020) and this rise population is mainly in developing countries (Jewell et al. 2010). Focus on sustainable agriculture is most essential to feed this increased population (Meena et al. 2017). This raised population is over-exploiting cultivated land and other available natural resources that causing climate change. The anthropogenic causes triggering global warming and climate change are ultimately adversely impacting in adverse wayson crop growth, yield, quality and agricultural sustainability (Godfray et al. 2010; Kumar et al. 2017; Nath et al. 2017). According to Fixen (2005) to feed the increased population with adequate amount and good standard food at an

How to cite this article: Palai, J.B., Malik, G.C., Maitra, S. and Banerjee, M. 2021. Role of Rhizobium on Growth and Development of Groundnut: A Review. IJAEB, 14(1): 63-73.

Source of Support: None; Conflict of Interest: None 
economical price, higher yield per unit area should be achieved with low cost of cultivation to full fill the requirement. Aim of crop nutrient management is increase in yield per unit amount of applied nutrient keeping priority on soil health and nutrient loss reduction which will result in higher nutrient use efficiency and sustainability (Ramakrishna et al. 2017). Using plenty of chemical nutrients and plant protection chemicals in agriculture showed negative effect on environment, soil and water (Godfray et al. 2010; Kumar et al. 2017; Nath et al. 2017). Similarly, improper use of chemical nutrients and pesticides recorded detrimental impacts on soil properties like reduction of soil fertility, physical properties, organic matter, water holding capacity, quality reduction of food and water due to agrochemicals as well as negative impact on biodiversity (Kamdi et al. 2014). The country experienced with the advantages Green Revolution Technologies (GRTs) in enhancing food grain production and also the ill impacts of GRTs afterwards in terms of declinein soil fertility as well as land degradation, enhancement of soil salinity in green revolution tracts in India, loss of soil flora and fauna, genetic erosion, ecological imbalance, yield plateauing and uncertainty in livelihood of the small and marginal farmers. Now, maintenance of soil fertility and sustainability of agriculture production are of great tasks (Maitra et al. 2018)..

Nowadays, people are more concerned about their health because of increased awareness and that resulted in increased demand of organic foods all over world. Organic agriculture is a production system that can offer enough scope for controlling environmental degradation, assuring ecosystem services and agricultural sustainability (Maitra et al. 2020). Bulky organic manures, concentrated organic manures and biofertilizers are the organic sources of nutrients, but these are not available with adequate quantity for high nutrient demanding crops (Patel et al. 2018). Mariana et al. (2020) reported that in present scenario preference for chemical free food is increasing among the people, so it became a challenging task to improve crop productivity in sustained manner with high quality. Moreover, Singh and Singh (2002) reported that getting higher yield irrespective of soil health and environmental condition is not advisable, so it needs importance towards sustainability in agriculture. There is no single resource which can meet all nutrient demand by a plant. Keeping all these in consideration, combined and judicious application of chemical, organic and biological nutrients can increase soil quality and supply sustained crop productivity. (Nagaraj et al. 2018) also mentioned that integrated use of chemical fertilizer, organic manure and biofertilizers is the most efficient way of nutrient management for higher sustained crop yield and soil fertility. Groundnut is a leguminous edible oilseed crop. Both in world wide as well as in India share of groundnut to total oilseed is considerable. Among all plant growth promoting rhizobacteria (PGPR), Rhizobium has important role in the form of biofertilizer inoculation in groundnut to improve plant growth and yield attributes and yield. The present study describes details about PGPR, Rhizobium and its influence on groundnut performance, soil fertility and interaction with other microorganisms.

\section{PGPR: Role in Plant Nutrient Management}

Rhizosphere was first studied by Hiltner (1904) and according to him soil within the vicinity of root system is having more bacterial population than nearby soil. Those bacteria also get profit as root secrets some metabolites which are the sources of nutrient for them and around $5-21 \%$ of plant fixed carbon is released from root exudates (Marschner 1995). Vessey (2003) reported that in plant rhizosphere several species of soil bacteria increase their population through various processes that promote plant growth are known as plant growth promoting rhizobacteria (PGPR). There are about $2-5 \%$ of PGPR in soil and they enhance the growth of the plant by plant infection (Kloepper and Schroth 1978). According to Somers et al. (2004), there are four types of PGPR as per the growth promoting traits and they are biofertilizers, phytostimulators, rhizo-remediators and biopesticides (Fig. 1).

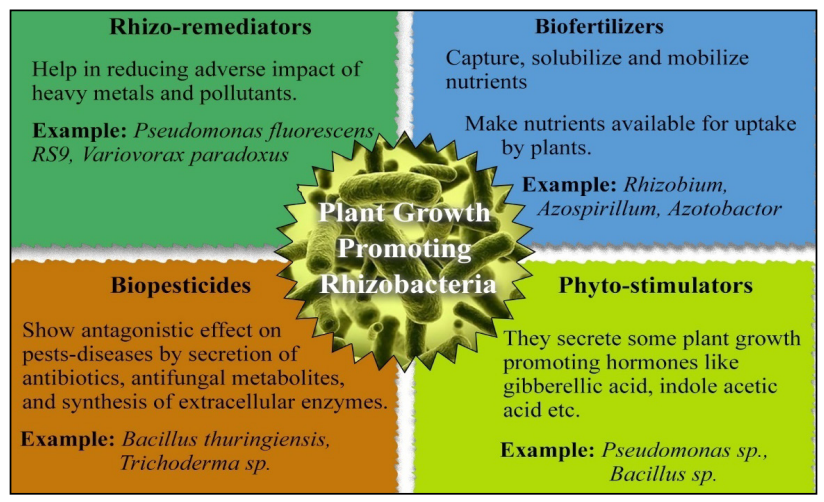

Fig. 1: Classification of plant growth promoting rhizobacteria (PGPR) (Somers et al. 2004) 
Another classification of PGPR has given by Gray and Smith (2005) as per the plant tissue compartment.

Extracellular PGPRs (ePGPRs) that exist in the rhizosphere, on the rhizoplane or in the spaces between cells of the root cortex. Example of these PGPRs are Agrobacterium, Arthrobacter, Azotobacter, Bacillus, Burkholderia, Caulobacter, Chromobacterium, Enterobacter, Enterococcus, Erwinia, Flavobacterium, Klebsiella, Micrococcus, Pseudomonas, Serratia and so on.

Intracellular PGPR (iPGPR) that exist inside root cells, generally in specialized nodular structures. Ex. Azorhizobium, Allorhizobium, Bradyrhizobium, Mesorhizobium/Ensifer, Rhizobiumand so on.

Most of the rhizobacteria are gram '-'ve and pleomorphic in nature and may be rod or cocci shaped with various colours such as creamy, white or translucent. Most of them show positive effect on plant growth. Microbial variation observed in rhizosphere are mainly with different plant growth promoting traits (Bhattacharyya and Jha 2012).

\section{Rhizobium, the Most Widely Used Biofertilizer for Legumes}

Legumes are well known soil fertility improver since ancient times and rhizobia was identified on later period. A publication on root nodulation in legumes was first written by Leonhard Fuchsius in 1542 (Fuchsius 1542) and Malpighi (1679) also found root nodules of Phaseolus vulgaris and Vicia faba. Boussingault (1838) in an experiment on legume crops and he recorded that there was increase in soil $\mathrm{N}$ content. Further, he was also the first who gave the concept of biological nitrogen fixation (BNF). Moreover, Lachmann (1858) took root nodules for microscopic study and reported that it consisted of vibrio like particles. After few years, Woronin (1866) mentioned that those particles were having properties like bacteria and the root nodules obtained from legumes belonging to a specific class of bacteria. Henceforth, in 1886, German scientists Hellriegel and Wilfarth observed that root nodules were able to fix atmospheric nitrogen and that created a milestone on symbiotic relation of Rhizobium and legumes. After two years,i.e., in 1888 , the Dutch microbiologist Beijerinck for the first time identified and isolated one bacterium from root nodule and he named it as Bacillus radicicola (Beijerinck 1888). But one year later, another microbiologist, Frank (1889) named it as Rhizobium leguminosarum. To utilize Rhizobium culture in agriculture commercially it was used as biofertilizer production in the name of Nitragin and it was patented by Nobbe and Hiltner (1896). In 1921, Löhis and Hansen classified them into two types as per their growth ability, as fast growers and slow growers. Concept of cross inoculation between some rhizobium species and legume plants as a host was given Baldwin and Fred (1929). At very beginning, people used to transfer soil from leguminous crop field to non-leguminous crop fieldor to seeds before planting, but later on, solid carrier-based formulations used for inoculation of Rhizobium (Fred et al. 1932) and liquid carrier-based formulation used in later period (Van Schreven et al. 1953; Singleton et al. 2002). Rhizobium is highly

Table 1: Response of some commonly experimented PGPR on different crops

\begin{tabular}{|c|c|c|c|c|c|}
\hline $\begin{array}{l}\text { Sl. } \\
\text { No. }\end{array}$ & PGPR & Plant & $\begin{array}{l}\text { Pot / field } \\
\text { experiment }\end{array}$ & Effect on plants & References \\
\hline 1 & $\begin{array}{l}\text { Pseudomonas putida } \\
\text { (GAP-P45) }\end{array}$ & Maize & Pot & $\begin{array}{l}\text { Performed best with respect to growth } \\
\text { and development in moisture stress } \\
\text { conditions }\end{array}$ & Sandhya et al. 2010 \\
\hline 2 & $\begin{array}{l}\text { Azospirillum } \\
\text { (45 L1) }\end{array}$ & Foxtail millet & Pot & $\begin{array}{l}\text { Showed higher panicle and seed } \\
\text { weight }\end{array}$ & Rafi et al. (2012) \\
\hline 4 & Rhizobium (USDA 3456) & Groundnut & Field & $\begin{array}{l}\text { Significantly higher haulm yield than } \\
\text { un-inoculated treatment }\end{array}$ & $\begin{array}{l}\text { Michael Asante et al. } \\
2020\end{array}$ \\
\hline 5 & $\begin{array}{l}\text { Bradyrhizobim } \\
\text { yuanmingense (BR 3267) }\end{array}$ & Groundnut & Field & $\begin{array}{l}\text { Significantly increased } 13 \text { to } 40 \% \text { pod } \\
\text { yield than un-inoculated treatment }\end{array}$ & $\begin{array}{l}\text { Michael Asante et al. } \\
(2020)\end{array}$ \\
\hline 6 & Azospirillum & Finger millet & Field & $\begin{array}{l}\text { Enhanced growth characters like plant } \\
\text { height, dry matter, leaf area index and } \\
\text { grain yield }\end{array}$ & Ramya et al. (2020) \\
\hline
\end{tabular}


host specific and suitable species should be chosen for different crops (Table 2). Earlier it was found that in groundnut crop the slow growing Bradyrhizobium Zhang et al. 1999; Chen et al. 2003; Yang et al. 2005) acted more efficiently for establishment of root nodules, whereas in recent past,it was observed that fast growing rhizobium efficiently acted for effective root nodulation (Khalid et al. 2015; Akhal et al. 2008; Rosália et al. 2005). NC 92, IGR 6, IGR 40, TAL 1000 and TNAU 14 are some superior stains of Bradyrhizobium that work efficiently and recommended for groundnut (ICAR 2009). It has been observed that Rhizobium activity, population and its effect on groundnut differs according to different agroecological conditions (Table 3).

Table 2: Rhizobium species suitable for different crops

\begin{tabular}{ll}
\hline Species of Rhizobium & Associated crops \\
\hline R. leguminosarum & Lathyrus, lentil, Peas (Pisum), Vicia \\
R. trifoli & Trifolium \\
R. phaseoli & Phaseolus \\
R. lupini & Lupinus \\
R. japonicum & Glycine max \\
R. meliloti & Fenugreek (Trigonella), Lucerne \\
& (Medicago), Melilotus \\
Cowpea miscellany & Acacia, Albizzia, Atylosia, blackgram, \\
& clusterbean, cowpea, Dalbergia, \\
& Glyricidia, greengram, groundnut, \\
& Indigofera, moth bean, Prosopis, \\
& redgram, Sesbania, Stylosanthes, \\
Separate group & sunnhemp, Tephrosia \\
\hline
\end{tabular}

Source: Hirsch et al. 2001; Datta et al. 2015; Reddy and Reddy, 2015.

\section{Groundnut, a Legume Oilseed}

Groundnut (Arachis hypogaea L.) is a self-fertilized annual leguminous oilseed crop and it is widely cultivated in the arid and semi-arid regions in the world $\left(40^{\circ} \mathrm{N}\right.$ and $\left.40^{\circ} \mathrm{S}\right)$ from equatorial region to warm temperate region. Semiarid tropics are the major growing zone of groundnut crop (Fletcher et al. 1992; Tarimo 1997). In the world, after soybean, rapeseed and mustard and sunflower, it is the fourth most common source of edible oil and third most important source of vegetable protein (Ojiewo et al. 2020). Groundnut is one of the most vital cash crops of India (Madhusudhana 2013). On an average, groundnut kernels contain $45-51 \%$ oil, $25 \%$ protein and $24.2 \%$ carbohydrates (Rajgopal et al. 2000). Groundnut is also rich in vitamins like B group and $E$ and rich in all the 20 essential amino acids among which arginine content is maximum. The calorific value of groundnut seed is $567 \mathrm{Kcal} / 100 \mathrm{~g}$ of seed (Arya et al. 2016). Globally major amount (53\%) of groundnut kernels is used for edible oil, $32 \%$ is consumed in confectionary and remaining quantity is used for food and seed production (Rajgopal et al. 2000). After oil extraction, the byproduct, i.e., oil cake, is used as cattle feed and concentrated organic manure (Rajgopal et al. 2000). Groundnut oil is rich in unsaturated fatty acids, such as poly unsaturated fatty acid (PUFA) (linoleic acid 25-35\%) and mono unsaturated fatty acid (MUFA) (oleic acid 40-50\%), moreover, it is very much suitable for deep frying because of its higher iodine value (ICAR-DGR, 2015). Worldwide groundnut area, production and productivity are 296 lakh ha, 488 lakh tone

Table 3: Effect of Rhizobium on groundnut under different agroecology

\begin{tabular}{|c|c|c|c|c|}
\hline $\begin{array}{l}\text { S1. } \\
\text { No. }\end{array}$ & Agroecology & Effect on groundnut & Rhizobium strain & References \\
\hline & Salt stress & Unable for nodulating & $\begin{array}{l}\text { Bradyrhizobium sp. } \\
\text { ATCC10317 }\end{array}$ & Dardanelli et al. (2009) \\
\hline & & Capable of nodulating & Bradyrhizobium sp TALl 371 & \\
\hline 2 & Soil acidity & Better performance in acidic soil & Bradyrhizobium sp. MAR 1510 & Rossum et al. (1994) \\
\hline 3 & $\begin{array}{l}\text { Nutrient solution } \\
\text { containing high carbonate }\end{array}$ & Nodulation inhibited & Rhizobium & Tang et al. (1998) \\
\hline 4 & Soil moisture deficiency & Little or no effect on N2-fixation & Rhizobium sp. & $\begin{array}{l}\text { Venkateswarlu et al. } \\
\text { (1989) }\end{array}$ \\
\hline 5 & Waterlogged condition & $\begin{array}{l}\text { Reduced Rhizobium population in } \\
\text { groundnut after rice cultivation }\end{array}$ & Rhizobium sp. & Dey and Pal (2014) \\
\hline
\end{tabular}


and $1647 \mathrm{~kg} / \mathrm{ha}$ respectively in 2019 (FAOSTAT, 2021). Globally, China is the largest producer of groundnut and India ranks second in groundnut production. Groundnut can be produced in diverse soil inclusive of light to heavy textured soil and the most suitable soil is light sandy-loam soil. Moreover, it requires warm climatic conditions with a nicely distributed rainfall ranging from 500 to $1000 \mathrm{~mm}$ (ICAR-DGR, 2015). In India, groundnut is grown in an area of 4.89 million hectare, with an yield of $1893 \mathrm{~kg} / \mathrm{ha}$ and production of 9.25 Million tons. In India, Gujarat is the highest producer of groundnut and its contribution is $42.55 \%$ of total production in the country. In 2013-14, India imported 0.11 thousand tons of groundnut by spending rupees 0.36 crore, whereas, in the same year it exported 509.75 thousand tons of groundnut and earned 3187.66 crore revenue (Agricultural statistics at a glance 2019, GOI).

According to Singh et al. (1997) biological criteria for lesser yield in oilseeds is due to conversion of one gram glucose produced from photosynthesis into $0.83 \mathrm{~g}$ starch, $0.4 \mathrm{~g}$ protein and only $0.32 \mathrm{~g}$ of lipids. Therefore, it needs additional inputs for higher yield. Nutrients required for groundnut to produce $2000-2500 \mathrm{~kg} / \mathrm{ha}$ of pod yield are $160-180 \mathrm{~kg}$ of $\mathrm{N}$, $20-25 \mathrm{~kg}$ of $\mathrm{P}, 80-100 \mathrm{~kg}$ of $\mathrm{K}, 60-80 \mathrm{~kg}$ of $\mathrm{Ca}, 15-20$ kg S, 30-45 kg Mg, 3-4 kg Fe, 300-400 g Mn, 150-200 g Zn, 140-180 g B, 30-40 g Cu and 8-10 g Mo (Singh, 1999). Both primary and secondary macronutrients have distinct role in kernel filling and oil synthesis, whereas, sulphur (Tandon 1991) and calcium are most essential of oil synthesis and pod formation respectively. Biofertilizers are prepared by using microorganisms which can reduce cost of cultivation and make it environment friendly (Gupta et al. 2003). Gradually, use of biofertilizer is getting more importance as it includes microbial culture either for seed inoculation or soil application which results in higher crop yield (Mahdi 1992). As the biofertilizers consists of living microbial culture, so it has beneficial influence on plant performances both directly and indirectly (FuentesRamirez and Caballero-Mellado 2005). Rhizobium forms nodule and fixes nitrogen biologically and thus, improve crop yield and soil quality (Fig. 2). (Chetti et al. 1995) found that highest growth parameters obtained from use of both Rhizobium and Phosphobacterium and that ultimately showed maximum dry matter accumulation in groundnut. Beneficial microorganisms present in the soil facilitate to increase nutrient availability. That's why plant growth promoting microorganisms (PGPM) has a distinct role in agriculture. Generally, PGPM includes both bacterial and fungal species. Use of plant growth promoting rhizobacteria (PGPR) is increasing steadily in all over world and showing positive influence on crop growth and productivity in most of the field crops which is a path towards sustainable agriculture (Sharma et al. 2016).

\section{Influence of Rhizobium on growth and yield parameter of groundnut}

Badawi et al. (2011) reported that Bradyrhizobium treated peanut crop resulted dry matter accumulation higher pod and straw yield than control. Basu et al. (2006) observed thatgrowth parameters of groundnut like plant height, number of branches per plant, leaf area index, number of nodules per plant were significantly higher with Rhizobium inoculation than the untreated treatments. Similarly,pod yield and haulm yield were also more with biofertilizer inoculation. Gunri et al. (2014) conducted an experiment on Red and Lataritic Zone of West Bengal and reported that groundnut seed inoculation with Rhizobium I (NRCG9) and Rhizobium II (IGR6) resulted significantly higher pod yield, haulm yield and number of pods per plant over control. Didagbé et al. (2014) studied on different strains of rhizobium in groundnut and noted that compared to control plant height was increased by $23 \%$ and $25 \%$ in case of WSM 4412 and STM5945 strain. They also reported that there were $38 \%$ and $33 \%$ increase in leaf number per plant by the application of STM 5894 and WSM 4412 strains of Rhizobium respectively. Laxminarayana and Patsram (2005) observed that groundnut seed inoculation with only Rhizobium without any organic manure or fertilizer application resulted higher pod yield than untreated control, but both were statistically at par with each other. But the same treatment resulted in significantly higher haulm yieldthan control. In another study, groundnut seed inoculated with NC-92 strain gave significantly higher nodules / plant, nodule dry weight/ plant than that of strain TAL-1371 and strain TAL-1000 (Ashraf et al. 2006). However, pods/plant, pod yield and haulm yield from the strain NC-92 
also resulted in significantly higher values other two strains of Rhizobium. Gomoung et al. (2017) reported that different Rhizobium strains collected from different crops improved seed yield of groundnut. A study clearly indicated that seed inoculation with Rhizobium in groundnut significantly increased the number of nodules, shoot and root dry matter yields than un-inoculated treatment (Yusif et al. (2016). Kumar and Suganya (2017) concluded that among five strains of Rhizobium (namely, RS1, RS2, RS3, RS4 and RS5) inoculated in groundnut seed, RS3 resulted in higher shoot length and root length, number of nodules and pod yield. Influence of Rhizobium inoculation on growth and yield of groundnut was also noted by Sajid et al. (2011) and they found that there was significantly higher growth parameters like plant height, number of shoots, number of leaves, number of nodules, number of pods and pod yield than un-inoculated treatment.

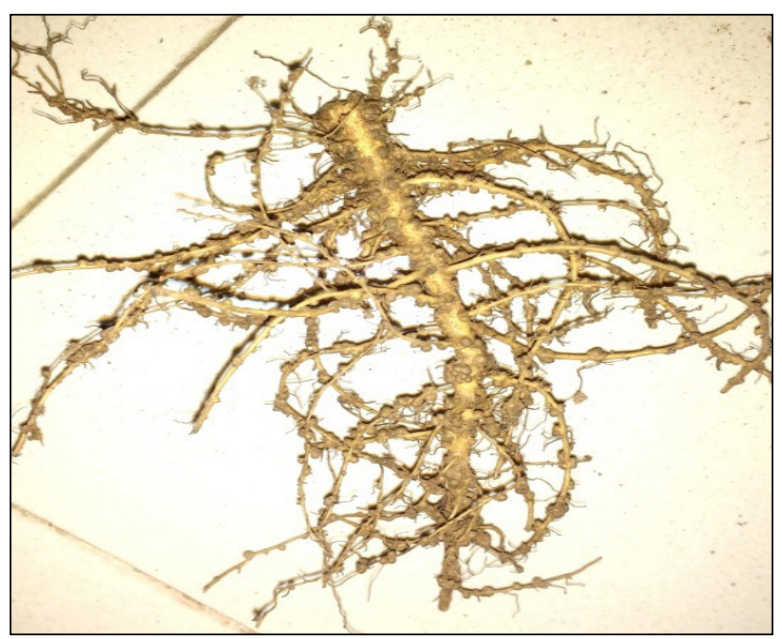

Fig. 2: Root nodule from Rhizobium inoculated groundnut plant (Picture taken by Jnana Bharati Palai)

\section{Interaction of Rhizobium with other PGPMS}

The interaction between Bradyrhizobium (strain LMG9283) and Arbuscular mycorrhizal fungus (Glomus intraradices) showed synergistic effect on yield of groundnut Sene et al. (2010). Combined application of Rhizobium and phosphorus solubilizing microorganism (PSM) enhanced germination percentage and root and shoot length of seedlings and 100 kernel weight than single inoculation with either Rhizobium or PSM (Singh et al. 2013).

In other leguminous crops also the combination of chemical fertilizer and different biofertilizers enhanced growth and productivity. Kumawat et al.
(2017) reported that combined application of 75\% recommended dose of fertilizer (RDF), Rhizobium and phosphate solubilizing bacteria (PSB) produced significantly higher seed and stover yields of fenugreek than $75 \%$ RDF and Rhizobium inoculation as seed treatment. Another prominent result indicated that yields of Vicia faba cv. Alborea coinoculated with Rhizobium leguminosarum bv. viceae $\mathrm{Z} 25 \mathrm{c}+$ Azotobacter vinelandii Dv42, R. leguminosarum bv. viceae Z25c + Azotobacter vinelandii ATCC 12837, R. leguminosarum bv. viceae Z25c + Azotobacter chroococcum $\mathrm{H} 23$ and $R$. leguminosarum bv. viceae $\mathrm{Z} 25 \mathrm{c}+$ Azospirillum brasilense Sp7 were respectively more by $140.6 \%, 147.2 \%, 151.5 \%$ and $136.4 \%$ than inoculation of $R$. leguminosarum bv. viceae Z25 alone (Rodelas et al. 1999). Effect of co-inoculation with Rhizobium and Bacillus cereus in pigeon pea in pot culture resulted in $382 \%$ increase in nodule number, $196 \%$ increase in nodule dry weight and 116\% increase in $\mathrm{N}$ fixation and $54 \%$ increase in grain yield (Tilak et al. 2006). In the same crop, they also tested co-inoculation of Rhizobium and Pseudomonas fluorescens and observed that 388\% increase in nodule number, $267 \%$ increase in nodule dry weight and $134 \%$ increase in $\mathrm{N}$ fixation and $66 \%$ increase in grain yield.

\section{Impact of Soil Nutrients on Activities of Rhizobium}

Efficiency of a BNF microorganisms is known in a nutrient deficient soil and it was found that root nodulation is less in soils rich in readily available nitrogen (Pitumpe et al. 2020; Zahran 1999). Soil treated with $100 \%$ RDN through inorganic fertilizers showed comparatively a smaller number of root nodule than soil treated with 100\% RDN through FYM and this indicated poor rhizobial activity in rich available nutrient (Baishya et al. 2014). Basically, phosphorus is a primary macronutrient, which helps in root development and nodule formation in legumes and plant growth Israel, (1987). Swarnalakshmi et al. (2020) mentioned that the bacteria which play major role efficiently in phosphorus solubilization are Bacillus, Pseudomonas and Rhizobium. As compared to fast multiplying rhizobia, slow multiplying rhizobia shows higher phosphorus deficiency tolerance (Beck and Munns 1985). There is also involvement of potassium (K) in nitrogen fixation. Sufficiency in potassium supply 
to plants increases carbohydrate accumulation due to higher photosynthesis and that allows better development of root nodules that ultimately results in higher nitrogen accumulation (Premaratne and Oertli, 1994).

Thomas and Hungria (1988) also suggested that potassium helps in transportation of nitrogenous compound from the $\mathrm{N}$-fixing site (nodule) to other parts of the plants which promotes Rhizobium for further $\mathrm{N}$ reduction. Not only macronutrients, but also there are influence of soil micronutrients on activities of Rhizobium. Adissie et al. (2020) did not find any significant grain yield enhancement in faba bean due to combined application of Rhizobium strain EAL 1035 and zinc (2 kg/ ha) compared to the separate application of both. But combined application of Rhizobium strain EAL 1035 and boron $(1.5 \mathrm{~kg} / \mathrm{ha})$ resulted in higher grain yield by $13.9 \%$ and $65.9 \%$ over second highest recorded treatment (Rhizobium strain EAL 1018 alone) and control treatment, respectively.

\section{Influence of Rhizobium on Soil Quality}

Khaitov et al. (2016) revealed that there was increase in soil fertility status such as carbon, nitrogen and phosphorus in their experiment on chickpea. According to them, there was increase in total nitrogen $\left(0.022\right.$ to $\left.0.033 \mathrm{~g} \mathrm{~kg}^{-1}\right)$, carbon $(0.054$ to 0.084 $\left.033 \mathrm{~g} \mathrm{~kg}^{-1}\right)$ and phosphorus (0.007 to $\left.0.015033 \mathrm{~g} \mathrm{~kg}^{-1}\right)$ content in Rhizobium inoculated chickpea field soil than control. Application of biofertilizer (Rhizobium and PSM) increased fertility status of post-harvest soil of summer groundnut such as $\mathrm{N}, \mathrm{P}_{2} \mathrm{O}_{5^{\prime}} \mathrm{K}_{2} \mathrm{O}$ and $\mathrm{S}$ by $14.79 \%, 8.34 \%, 2.96 \%, 30.29 \%$ respectively than untreated control (Vala et al. 2018). Effect of Rhizobium inoculation in groundnut improved residual soil fertility status higher than control in terms of enrichment of N, P and K status of the postharvest soil (Laxminarayana and Patsram 2005). Yusif et al. (2016) also observed similar result such as Rhizobium inoculated treatment in groundnut showed higher organic carbon, available N, P, K, Ca and $\mathrm{Mg}$ than Rhizobium un-inoculated treatment in post-harvest soil. Further, legumes are well known for symbiotic association with micro-organisms. Other than symbiotic Rhizobium, other free-living soil bacteria like Arthrobacter simplex, Bacillus laevolacticus, B. amyloliquefaciens, Pseudomonas denitrificans, and P. rathonis, and all aerobic or facultative anaerobic heterotrophic soil species, have been found to propagate more in presence of Rhizobium to promote plant growth (Maitra and Ray 2019; Qiao et al. 2012; Spehn et al. 2000).

\section{CONCLUSION}

From the beginning of crop cultivation importance of legumes with respect to soil health and sustainability is very well known. Use of chemical fertilizers in the post Green revolution era undoubtedly enhanced agricultural productivity, but it happened at a cost of agricultural sustainability. After realizing the adverse impacts of chemical inputs in agriculture, focus has been shifted to integrated management of nutrients and pests to reduce use of chemicals. Further, organic agriculture has created a huge potential for enhancing profitability in agriculture through export of organic produces. Both the approaches have created an enormous opportunity of using microbial inputs in ecofriendly agriculture. Earlier researches evidenced that inclusion of PGPR and as specially Rhizobium in groundnut improved crop yield, nutrient uptake and facilitated maintenance of soil fertility along with multiple environmental benefits. The review article concludes that targeting a higher productivity of groundnut and improving soil quality, Rhizobium inoculation can be preferred. Further, beneficial roles of Rhizobium and other PGPRs may lead towards agricultural sustainability.

\section{REFERENCES}

Adissie, S., Adgo, E. and Feyisa, T. 2020. Effect of rhizobial inoculants and micronutrients on yield and yield components of faba bean (Vicia faba L.) on vertisol of Wereillu district, South Wollo, Ethiopia, Cogent Food \& Agriculture, 6(1): 1747854.

Agricultural statistics at a glance 2019 (2020) Directorate of Economics \& Statistics, Government of India. https:// eands.dacnet.nic.in/PDF/At\%20a\%20Glance $\% 202019 \% 20$ Eng.pdf (Accessed on 15 March 2021)

Arya, S.S., Salve, A.R. and Chauhan, S. 2016. Peanuts as functional food: a review. J. Food Sci. Technol., 53(1): 31-41.

Ashraf, M., Ahmad, M. and Bakush, H.M. 2006. Efficacy of rhizobium strains for groundnut inoculation under rain fed conditions. Pak. J. Agri. Sci., 43(3-4): 122-125.

Badawi, F.S.F., Biomy, A.M.M. and Desoky, A.H. 2011. Peanut plant growth and yield as influenced by co-inoculation with Bradyrhizobium and some rhizo-microorganisms under sandy loam soil conditions. Ann. Agric. Sci., 56: $17-25$. 
Baishya, L.K., Ansari, M.A., Singh, R., Deka, B.C., Prakash, N. and Ngachan, S.V. 2014. Response of groundnut (Arachis hypogaea) cultivars to integrated nutrient management on productivity, profitability and nutrient uptake in $\mathrm{NEH}$ Region. Indian J. Agric. Sci., 84(5): 612-615.

Baldwin, I.L. and Fred, E.B. 1929. Nomenclature of the root nodule bacteria of the Leguminosae. J. Bacteriol., 17: 141-150.

Basu, M., Bhadoria, P.B.S. and Mahapatra, S.C. 2006. Influence of microbial culture in combination with micronutrient in improving the groundnut productivity under alluvial soil of India. Acta Agric. Slov., 87(2): 435 - 444.

Beck, D.P. and Munns, D.N. 1985. Effect of calcium on the phosphorus nutrition of Rhizobium meliloti. Soil Sci. Soc. Am. J., 49: 334-337.

Beijerinck, M.W. 1888. Cultur des Bacillus radicicola aus den Kno"llchen. Bot. Ztg., 46: 740-750.

Bhattacharyya, P.N. and Jha, D.K. 2012. Plant growth promoting rhizobacteria (PGPR): emergence in agriculture. World J. Microbiol. Biotechnol., 28: 1327-1350.

Boussingault, J. 1838. Recherches chimiques sur la vegetation enterprises dans le but d'examinersi les plantes prennent de I'atmosphere. Ann. Chim. Phys., 67: 1-54.

Chen, Q., Zhang, X., Terefework, Z., Kaijalainen, S., Li, D. and Lindström, K. 2003. Diversity and compatibility of peanut (Arachis hypogaea L.) bradyrhizobia and their host plants. Plant Soil, 255: 605-617.

Chetti, M.B., Antony, E., Mummigatti, U.V. and Dodamani, M.B. 1995. Role of nitrogen and Rhizobium on nitrogen utilization efficiency and productivity potential in groundnut genotypes. Farming Systems, 11(1-2): 209-216.

Dardanelli, M.S., González, P.S., Medeot, D.B., Natalia, S.P., Miguel, A.B. and Mirta, B.G. 2009. Effects of peanut rhizobia on the growth and symbiotic performance of Arachis hypogaea under abiotic stress. Symbiosis, 47: 175-180.

Datta, A., Singh, R.K., Kumar, S. and Kumar, S. 2015. An Effective and Beneficial Plant Growth Promoting Soil Bacterium"Rhizobium": A Review. Ann. Plant Sci., 4(01): 933-942.

Dey, R. and Pal, K.K. 2014. Biofertilizers for enhancing groundnut productivity. ICAR-Directorate of Groundnut Research, Ivnagar Road, PB No. 5, Junagadh, Gujarat, India, pp. 30.

Didagbé, O.Y., Houngnandan, P., Sina, H., Zoundji, C.C., Kouelo, F.A., Lakou, J., Toukourou, F., Baba-Moussa, L. 2014. Response of groundnut (Arachis hypogaea L.) to exogenous Bradyrhizobium sp strains inoculation and phosphorus supply in two agro-ecological zones of Benin, West Africa. J. Exp. Biol. Agric. Sci., 2(6): 623-633.

El-Akhal, M.R., Rincón, A., Arenal, F., Lucas, M.M., ElMourabit, N., Barrijal, S. and Pueyo, J.J. 2008. Genetic diversity and symbiotic efficiency of rhizobial isolates obtained from nodules of Arachis hypogaea in northwestern Morocco. Soil Biol. Biochem., 40: 2911-2914.
FAOSTAT. 2021. Crop Statistics. http://www.fao.org/faostat/ en/\#data/QC. Accessed on 15 March 2021.

Fixen, P.E. 2005. Understanding and improving nutrient use efficiency as an application of information technology. In: Proceedings of the Symposium on Information Technology in Soil Fertility and Fertilizer Management, a satellite symposium at the XV International Plant Nutrient Colloquium, Sep. 14-16, 2005. Beijing, China.

Fletcher, S.M., Zhang, P. and Carley, D. 1992. Groundnuts: Production, Utilization and trade in the 1980s.

Frank, B. 1889. Ueber die Pilzsymbiose der Leguminosen. Ber Deut Bot Ges., 7: 332-346.

Fred, E.B., Baldwin, I.L. and McCoy, E. 1932. Root nodule bacteria and leguminous plants, University of Wisconsin Studies in Science No.5. University of Wisconsin, Madison.

Fuchsius, L. 1542. De historia stirpium commentarii isignes. Michael Isingrin, Basel.

Fuentes-Ramirez, L.E. and Caballero-Mellado, J. 2005. Bacterial Biofertilizers. In PGPR: Biocontrol and Biofertilization; Springer: Berlin/Heidelberg, Germany.

Godfray, H.C.J., Beddington, J.R., Crute, I.R., Haddad, L., Lawrence, D., Muir, J.F., Pretty, J., Robinson, S., Thomas, S.M. and Toulmin, C. 2010. Food Security: The Challenge of Feeding 9 Billion People. Science, 327: 812-818.

Gomoung, D., Mbailao, M., Toukam, S.T. and Ngakou, A. 2017. Influence of Cross-Inoculation on Groundnut and Bambara Groundnut-Rhizobium Symbiosis: Contribution to Plant Growth and Yield in the Field at Sarh (Chad) and Ngaoundere (Cameroon). Am. J. Plant Sci., 8: 1953-1966.

Gray, E.J. and Smith, D.L. 2005. Intracellular and extracellular PGPR: commonalities and distinctions in the plant bacterium signaling process. Soil Biol. Biochem., 37: 395-412.

Gunri, S.K., Biswas, T., Mandal, G.S., Nath, R. and Kundu, C.K. 2014. Effect of biofertilizer on productivity of groundnut (Arachis hypogaea L.) in red and laterite zone of West Bengal. Karnataka J. Agric. Sci., 27(2): 230-231.

Gupta, R.K., Kaushik, S., Sharma, P. and Jain, V.K. 2003. Biofertilizers: An eco-friendly alternative to chemical fertilizers. Environmental Challenges of the $21^{\text {st }}$ Century, APH Publishing Corporation, New Delhi, pp. 275-287.

Hellriegel, H. and Wilfarth, H. 1888. Untersuchungen u“ ber die Stickstoffnahrung der Gramineon und Leguminosen. Beilageheft zu der Ztschr. Ver. Ru“ benzucker-Industrie Deutschen Reichs.

Hiltner, L. 1904. Uber neuere Erfahrungen und Probleme auf dem Gebiete der Bodenbakteriologie unter bessonderer Beru“cksichtigung der Gründung und Brache. Arb Dtsch Landwirtsch Ges Berl., 98: 59-78.

Hirsch, A.M., Lum, M.R. and Downie, J.A. 2001. What Makes the Rhizobia-Legume Symbiosis So Special? Plant Physiol., 127(4): 1484-1492.

ICAR. 2009. Hand book of agriculture, $6^{\text {th }}$ edition, New Delhi, India.

ICAR-Directorate of Groundnut Research (DGR), Gujarat 2015. Vision-2050. http://www.dgr.org.in/wp-content/ 
uploads/2019/06/VISION-2050.pdf (Accessed on $15^{\text {th }}$ March 2021)

IISD. 2020. News. https://sdg.iisd.org/news/world-populationto-reach-9-9-billion-by-2050/. Accessed on 15 March 2021.

Israel, D.W. 1987. Investigation of the role of phosphorus in symbiotic dinitrogen fixation. Plant Physiol., 84: 835-840.

Jewell, M.C., Campbell, B.C. and Godwin, I.D. 2010. Transgenic Plants for Abiotic Stress Resistance. In Transgenic Crop Plants; Springer: Berlin/Heidelberg, Germany

Kamdi, T.S., Sonkamble, P. and Joshi, S. 2014. Effect of organic manure and biofertilizers on seed quality of groundnut (Arachis hypogaea L.). The Bioscan., 9(3): 1011-1013.

Khaitov, B., Kurbonov, A., Abdiev, A. and Adilov, M. 2016. Effect of chickpea in association with Rhizobium to crop productivity and soil fertility. Eurasian J. Soil Sci., 5(2): $105-112$.

Khalid, R., Zhang, Y.J., Ali, S., Sui, X.H., Zhang, X.X., Amara U., Chen, W.X. and Hayat, R. 2015. Rhizobium pakistanensis sp. nov., isolated from groundnut (Arachis hypogaea) nodules grown in rainfed Pothwar, Pakistan. Antonie Van Leeuwenhoek, 107: 281-290.

Kloepper, J.W. and Schroth, M.N. 1978. Plant growth promoting rhizobacteria on radishes. In: Proceedings of the $\mathrm{IV}^{\text {th }}$ international conference on plant pathogenic bacteria, Station de Pathologie Vegetale et Phyto-Bacteriologie, Angers, 2: 879-882.

Kumar, A., Maurya, B.R., Raghuwanshi, R., Meena, V.S. and Tofazzal, I.M. 2017. Co-inoculation with enterobacter and rhizobacteria on yield and nutrient uptake by wheat (Triticum Aestivum L.) in the alluvial soil under IndoGangetic plain of India. J. Plant Growth Regul., 36: 608-617.

Kumar, S.R.A. and Suganya, A. 2017. Potential for Plant Growth Promotion in Groundnut (Arachis hypogaea L.) by Inoculation of Native Rhizobium Strains. Int. J. Sci. Res., 6(4): 2069-2072.

Kumawat, K., Patel, P.P., Dambiwal, D., Reddy, T.V., Chouthu, Ram Hakla C.P. 2017. Effect of liquid and solid biofertilizers (Rhizobium and PSB) on growth attributes, yield and economics of fenugreek (Trigonella foenum-graecum L.). Int. J. Chem. Stud., 5(4): 239-242.

Lachmann, J. 1858. Über knollen an den wurzeln der leguminosen (About bulbous roots of the legume). Landwirthschaftliche Mitteilungen. Z Koniglichen.

Laxminarayana, K. Patsram. 2005. Influence of inorganic, biological and organic manures on yield and nutrient uptake of groundnut (Arachis hypogaea) and soil properties. Indian J. Agric. Sci., 75(4): 218-221.

Löhis, F. and Hansen, R. 1921. Nodulating bacteria of leguminous plant. J. Agric. Res., 20: 543-556.

Madhusudhana, B. 2013. A Survey on Area, Production and Productivity of Groundnut Crop in India. J. Financ Econ., 1(3): 2321-5925.

Mahato, S. and Kafle, A. 2018. Comparative study of Azotobacter with or without other fertilizers on growth and yield of wheat in Western hills of Nepal. Ann. Agrar. Sci., 16: 250-256.
Mahdi, A.A. and Atabani, I.M.A. 1992. Response of Bradyrhizobium inoculated soybean and lablab bean to inoculation with vesicular mycorrhizae. Exp. Agric., 28: 399-407.

Maitra, S. and Ray, D.P. 2019. Enrichment of Biodiversity, Influence in Microbial Population Dynamics of Soil and Nutrient Utilization in Cereal-Legume Intercropping Systems: A Review. Int. J. Bioresource Sci., 6(1): 11-19.

Maitra, S., Shankar, T., Gaikwad, D.J., Palai, J.B. and Sagar, L. 2020. Organic Agriculture, Ecosystem Services and Sustainability: A Review. Int. J. Mod. Agric., 9(4): 370-378.

Maitra, S., Zaman, A., Mandal, T.K. and Palai, J.B. 2018. Green manures in agriculture: A review. J. Pharmacogn. Phytochem., 7(5): 1319-1327.

Malpighi, H. 1679. Anatome plantarum. J Martyn London.

Marschner, H. 1995. Mineral nutrition of higher plants, $2^{\text {nd }}$ edn. Academic, London

Meena, V.S., Meena, S.K., Verma, J.P., Kumar, A., Aeron, A., Mishra, P.K., Bisht, J.K., Pattanayak, A., Naveed, M. and Dotaniya, M.L. 2017. Plant beneficial rhizospheric microorganism (PBRM) strategies to improve nutrients use efficiency: A review. Ecol. Eng., 107: 8-32.

Michael, A., Ahiabor, B.D.K. and Atakora, W.K. 2020. Growth, Nodulation, and Yield Responses of Groundnut (Arachis hypogaea L.) as Influenced by Combined Application of Rhizobium Inoculant and Phosphorus in the Guinea Savanna Zone of Ghana. Int. J. Agron., pp. 1-7.

Nagaraj, R., Hanumanthappa, M. and Kamath, S. 2018. Growth parameters and yield of groundnut as influenced by integrated nutrient management at coastal zone of Karnataka. J. Pharmacogn. Phytochem., 7(5): 2725-2729.

Nath, D., Maurya, B.R. and Meena, V.S. 2017. Documentation of five potassium- and phosphorus-solubilizing bacteria for their $\mathrm{K}$ and P-solubilization ability from various minerals. Biocatal Agric. Biotechnol., 10: 174-181.

Nobbe, F. and Hiltner, L. 1896. Inoculation of the soil for cultivating leguminous plants. U.S. Patent 570813.

Ojiewo, C., Janila, P., Bhatnagar-Mathur, P., Pandey, M.K., Desmae, H., Okori, P., Mwololo, J., Ajeigbe, H., NjugunaMungai, E. and Muricho, G. 2020. Advances in crop improvement and delivery research for nutritional quality and health benefits of groundnut (Arachis hypogaea L.). Front Plant Sci., 11: 1-15.

Patel, A.M., Patel, P.K., Saini, A.K. and Patel, K.M. 2018. Organic nutrient management packages of green manuring potato groundnut sequence. Int. J. Agric. Sci., 10(10): 6025-6027.

Pitumpe, A.P.S., Rosso, L.H.M. and Hansel, F.D. 2020. Temporal biological nitrogen fixation pattern in soybean inoculated with Bradyrhizobium. Agrosyst. Geosci. Environ., 3(1): 1-10.

Premaratne, K.P. and Oertli, J.J. 1994. The influence of potassium supply on nodulation, nitrogenase activity and nitrogen accumulation of soybean (Glycine max L. Merrill) grown in nutrient solution. Ferti. Res., 38(2): 95-99. 
Qiao, Y.J., Li, Z.Z., Wang, X., Zhu, B., Hu, Y.G. and Zeng, Z.H. 2012. Effect of legume-cereal mixtures on the diversity of bacterial communities in the rhizosphere. Plant Soil Environ., 58(4): 174-180.

Rafi, M.M.D., Varalakshmi, T. and Charyulu, P.B.B.N. 2012. Influence of Azospirillum and PSB inoculation on growth and yield of Foxtail Millet. J. Microbiol. Biotechnol., 2(4): 558-565.

Rajgopal, K.K., Chandan, J.B., Mishra, P.K., Bhaodia, Mathur, R.S. 2000. Evaluation of bold seed nut groundnut accessions for confectionery attributes. IAN 20: 18-19.

Ramakrishna, K., Devi, S., Sailaja, K.B. and Saritha, J.D. 2017. Nutrient use efficiency of groundnut with organic manures. Environ. Conserv. J., 18(3): 1-8.

Ramya, P., Maitra, S., Shankar, T., Adhikary, R. and Palai, J.B. 2020. Growth and Productivity of Finger Millet (Eleusine coracana L. Gaertn) as Influenced by Integrated Nutrient Management. Agric Econ., 7(2): 17-24 (Special Issue).

Reddy, T.Y. and Reddy, G.S. 2016. Principles of agronomy, $5^{\text {th }}$ edition. New Delhi, India

Rodelas, R., González-López, J., Martínez-Toledo, M.V., Pozo, C. and Salmerón, V. 1999. Influence of Rhizobium/ Azotobacter and Rhizobium/Azospirillum combined inoculation on mineral composition of faba bean (Vicia faba L.). Biol. Ferti. Soils, 29: 165-169.

Roriz, M., Carvalho, S.M.P., Castro, P.M.L. and Vasconcelos, M.W. 2020. Legume biofortification and the role of plant growth-promoting bacteria in a sustainable agricultural era. Agronomy, 10(3): 1-13.

Rosália, C.E., Santos, S., Stamford, N.P., Freitas, A.D.S., Vieira, I.M.D.M.B., Souto, S.M., Neves, M.C.P. and Rumjanek, N.G. 2005. Efetividade de rizóbios isolados de solos da região Nordeste do Brasil na fixação do N2 em amendoim (Arachis hypogaea L.). Acta Scientiarum Agron., 27: 301-307.

Sajid, M., Rab, A., Fazal-I-Wahid, Shah, S.N.M., Jan, I., Khan, M.A., Hussain, S.A., Khan, M.A. and Iqbal, Z. 2011. Influence of rhizobium inoculation on growth and yield of groundnut cultivars. Sarhad J. Agric., 27(4): 573-576.

Sandhya, V., Ali, S.Z. and Grover, M. 2010. Effect of plant growth promoting Pseudomonas spp. on compatible solutes, antioxidant status and plant growth of maize under drought stress. Plant Growth Regul., 62: 21-30.

Sene, G., Thiao, M., Mbaye, R.S., Ndoye, F., Kane, A., Diouf, D. and Sylla, S.N. 2010. Response of three peanut cultivars toward inoculation.

Sharma, P., Kumawat, K.C. and Kaur, S. 2016. Plant Growth Promoting Rhizobacteria in Nutrient Enrichment: Current Perspectives. In: Singh U, Praharaj C, Singh S, Singh N (eds) Biofortification of Food Crops. Springer, New Delhi. https://doi.org/10.1007/978-81-322-2716-8_20

Singh, A.L. 1999. Mineral Nutrition of Groundnut. In Advances in Plant Physiology (Ed. A. Hemantranjan), Vol II pp. 161-200. Scientific Publishers (India), Jodhpur, India.

Singh, A.L., Ghosh, P.K. and Dayal, D. 1997. Nutrient management in groundnut and groundnut based cropping systems. In: Ghonsikar CP, Shinde VS (Eds)
Nutrient Management Practices in crops and cropping Systems, India

Singh, B. and Singh, Y. 2002. Concepts in nutrient management. In: Recent Advances in Agronomy. Indian Soc Agron, New Delhi, 92-109.

Singh, G.P., Singh, P.L. and Panwar, A.S. 2013. Seed yield, quality and nutrient uptake of groundnut (Arachis hypogaea) as affected by integrated nutrient management in mid hill altitude of Meghalaya, India. Legum. Res., 36(2): 147-152.

Singleton, P., Keyser, H. and Sande, E. 2002. Development and evaluation of liquid inoculants. In: Herridge D (ed) Inoculants and nitrogen fixation of legumes in Vietnam, ACIAR Proceedings, Canberra, 109: 52-66.

Somers, E., Vanderleyden, J. and Srinivasan, M. 2004. Rhizosphere bacterial signalling: a love parade beneath our feet. Crit. Rev. Microbiol., 30: 205-240.

Spehn, E.M., Joshi, J., Schmid, B., Alphei, J. and Korner, C. 2000. Plant diversity effects on soil heterotrophic activity in experimental grassland ecosystems. Plant Soil, 224: 217-230.

Swarnalakshmi, K., Yadav, V., Tyagi, D., Dhar, D.W., Kannepalli, A. and Kumar, S. 2020. Significance of plant growth promoting rhizobacteria in grain legumes: growth promotion and crop production. Plants, 9: 1596.

Tandon, H.L.S. 1991. Sulphur Research and Agriculture Production. FDCO, $3^{\text {rd }}$ edition, New Delhi, India.

Tang, C., Barton, L. and Raphael, C. 1998. Pasture legume species differ in their capacity to acidify soil. Aust. J. Agric. Res., 49(1): 53-58.

Tarimo, A.J.P. 1997. Physiological response of groundnut to plant population density. African Crop Sci. J., 5(3): 267-272.

Thomas, R.J. and Hungria, M. 1988. Effect of potassium on nitrogen fixation, nitrogen transport, and nitrogen harvest index of bean. J. Plant Nutr., 11(2):175-188.

Tilak, K.V.B.R., Ranganayaki, N. and Manoharachari, C. 2006. Synergistic effects of plant-growth promoting rhizobacteria and Rhizobium on nodulation and nitrogen fixation by pigeonpea (Cajanus cajan). Eur. J. Soil Sci., 57: $67-71$.

Vala, F.G., Vaghasia, P.M., Zala, K.P. and Akhatar, N. 2018. Response of Integrated Nutrient Management on Nutrient Uptake, Economics and Nutrient Status of Soil in Bold Seeded Summer Groundnut. Int. J. Curr. Microbiol. App. Sci., 7(1): 174-180.

Van Rossum, D., Muyotcha, A., De Hope, B.M., Van Verseveld, H.W., Stouthamer, A.H. and Boogerd, F.C. 1994. Soil acidity in relation to groundnut-Bradyrhizobium symbiotic performance. Plant Soil, 163: 165-175.

Van Schreven, D.A., Harmsen, G.W. and Lindenbergh, D.T. 1953. Experiments on the cultivation of Rhizobium in liquid media for use on zindderzee polders. Antonie van Leeuwenhoek, 19: 300-308.

Venkateswarlu, B., Maheswari, M. and Karan, N.S. 1989. Effects of water deficits on $\mathrm{N}_{2}\left(\mathrm{C}_{2} \mathrm{H}_{2}\right)$ fixation in cowpea and groundnut. Plant Soil, 114: 69-74. 
Vessey, J.K. 2003. Plant growth promoting rhizobacteria as biofertilizers. Plant Soil, 255: 571-586

Woronin, M.S. 1866. Uber die bei der Schwarzerle (Alnus glutinosa) und bei der gewo"hnlichen Gartenlupine (Lupinus mutabilis) auftretenden Wurzelanschwellungen. Me'moires del'Academie Impe'riale des Sciences de St. Pe'tersbourg, VII Series, vol. $\mathrm{X}$

Yang, J.K., Xie, F.L., Zou, J., Zhou, Q. and Zhou, J.C. 2005. Polyphasic characteristics of bradyrhizobia isolated from nodules of peanut (Arachis hypogaea) in China. Soil Biol. Biochem., 37: 141-153.

Yusif, S.A., Muhammad, I., Hayatu, N.G., Sauwa, M.M., Tafinta, I.Y., Mohammed, M.A., Lukman, S.A., Abubakar, G.A. and Hussain, A.M. 2016. Effects of Biochar and Rhizobium Inoculation on Nodulation and Growth of Groundnut in Sokoto State, Nigeria. Appl. Life Sci. Int., 9(2): 1-9.
Zahran, H.H. 1999. Rhizobium-legume symbiosis and nitrogen fixation under severe conditions and in an arid climate. Microbiol. Mol. Biol. Rev., 63(4): 968-989.

Zhang, X., Nick, G., Kaijalainen, S., Terefework, Z., Paulin, L., Tighe, S.W., Graham, P.H. and Lindström, K. 1999. Phylogeny and diversity of Bradyrhizobium strains isolated from the root nodules of peanut (Arachis hypogaea) in Sichuan, China. Syst. Appl. Microbiol., 22: 378-386. 
